\title{
UJI DAYA HAMBAT EKSTRAK BAWANG PUTIH (Allium Sativum) TERHADAP BAKTERI (Staphylococcus Aureus)
}

\author{
Yusril Ilham Fahmi*, Ana Andriana**, Diani Sri Hidayati*** \\ Fakultas Kedokteran Universitas Islam Al-Azhar \\ Jl. Unizar No. 20 Turida Mataram
}

\begin{abstract}
ABSTRAK
Mikroorganisme alami yang ada dalam tubuh manusia disebut mikroorganisme normal atau flora normal, namun dalam keadaan tertentu dapat bersifat patogen dan menimbulkan penyakit infeksi salah satunya Staphylococcus Aureus. Bakteri ini sering resisten terhadap berbagai jenis obat sehingga mempersulit pemilihan antimikroba yang sesuai untuk terapi. Bawang putih (Allium Sativum) mempunyai bahan aktif yaitu alicin, flavonoid, ajoene, minyak atsiri dan saponin yang mempunyai efek antimikroba. Tujuan penelitian ini adalah mengetahui daya hambat ekstrak bawang putih (Allium Sativum) terhadap pertumbuhan bakteri Staphylococcus aureus.

Penelitian ini merupakan jenis penelitian True Experiment dengan rancangan Posttest dengan Kelompok Kontrol (Posttest Only Control Group Design), menggunakan Rancangan Acak Lengkap (RAL) dengan 24 perlakuan dan 4 kali ulangan. Sampel yang digunakan dalam penelitian ini adalah bakteri Staphylococcus aureus yang diberi perlakuan ekstrak bawang putih (Allium Sativum) dengan konsentrasi $250 \mu \mathrm{g} / \mathrm{mL}, 500 \mu \mathrm{g} / \mathrm{mL}, 750 \mu \mathrm{g} / \mathrm{mL}, 1000 \mu \mathrm{g} / \mathrm{mL}, 2$ kelompok kontrol terdiri dari kontrol positif ciprofloksasin dan kontrol negatif aquades steril. Daya hambat diperoleh berdasarkan pengukuran zona hambat dan data yang diperoleh dari analisis menggunakan uji One Way Anova.

Hasil pengukuran zona hambatan bakteri Staphylococcus aureus pada masing-masing konsentrasi berturut turut adalah, konsentrasi $250 \mu \mathrm{g} / \mathrm{mL}$ sebesar $6.5 \mathrm{~mm} ; 500 \mu \mathrm{g} / \mathrm{mL}, 13.3 \mathrm{~mm}$; $750 \mu \mathrm{g} / \mathrm{mL}, 15 \mathrm{~mm}$ dan $1000 \mu \mathrm{g} / \mathrm{mL}, 17.8 \mathrm{~mm}$. Pada konsentrasi yang paling tinggi menghasilkan daerah zona hambat yang terlebar. Hasil uji One Way Anova diperoleh nilai signifikan yakni 0,008 lebih kecil dari $p$ value: 0,05 sehingga dapat dinyatakan bahwa konsentrasi ekstrak bawang putih (Allium Sativum) dapat mempengaruhi pertumbuhan bakteri Staphylococcus Aureus.
\end{abstract}

Kata Kunci : Staphylococcus Aureus, Bawang Putih, Zona Hambat.

\section{PENDAHULUAN}

Penyakit infeksi masih merupakan penyakit yang paling banyak diderita oleh penduduk di negara berkembang termasuk Indonesia. Salah satu penyebab penyakit infeksi adalah bakteri. Mikroorganisme alami yang ada dalam tubuh manusia disebut mikroorganisme normal atau flora normal, namun dalam keadaan tertentu dapat bersifat patogen dan menimbulkan penyakit infeksi salah satunya Staphylococcus Aureus (Price dan Wilson, 2012).

\section{Staphylococcus}

Aureus

menyebabkan infeksi pada luka berupa abses yang merupakan kumpulan nanah atau cairan dalam jaringan (Wahyudi dan Sukarjati, 2013). Staphylococcus Aureus juga dapat menimbulkan infeksi yang lebih berat seperti pneumonia, mastitis, phlebitis, meningitis, infeksi saluran kemih, osteomielitis, endokarditis, dan keracunan makanan serta penyebab terjadinya infeksi nosokomial (Ansari et. Al., 2016). Infeksi nosokomial disebut juga dengan Hospital Acquired Infection (HAI) adalah infeksi yang didapatkan dan berkembang selama pasien dirawat di rumah sakit (WHO, 2013). Terjadinya infeksi nosokomial paling sering pada 
saat pasca operasi, infeksi saluran kemih, infeksi saluran nafas dan infeksi aliran darah (Kemenkes, 2013). Penyebab infeksi nosokomial yang terjadi di rumah sakit umumnya disebabkan oleh dua faktor, yaitu faktor internal meliputi flora normal dari pasien itu sendiri dan faktor eksternal meliputi lingkungan rumah sakit, makanan, udara, pemakaian infus, pemakaian kateter dalam waktu lama dan tidak diganti-ganti, serta benda dan bahan-bahan yang tidak steril (Kowalski, 2007).

Infeksi yang diakibatkan bakteri Staphylococcus Aureus biasanya diatasi dengan pemberian antibiotik, akan tetapi pada beberapa kasus telah ditemukan beberapa strain Staphylococcus Aureus yang resisten terhadap antibiotik seperti Methicillin-Resistant Staphylococcus Aureus (MRSA) (Tokajian, 2014). Bahaya resistensi antibiotik saat ini menjadi masalah kesehatan dunia yang serius baik di negara maju maupun negara berkembang. Meningkatnya resistensi bakteri terhadap antibiotik, memunculkan penggunaan tanaman herbal sebagai alternatif pengganti yang memiliki efek samping yang kecil apabila dibandingkan dengan obat-obat yang diformulasikan dari bahan kimia. Salah satu tanaman yang telah lama dipercaya memiliki aktivitas antibakteri yang cukup baik terhadap bakteri ialah bawang putih (Allium Sativum) (Duman, 2008).
Tanaman bawang putih (Allium Sativum) adalah salah satu tanaman tradisional yang sudah lama digunakan dalam pengobatan untuk berbagai jenis penyakit (Fulder, et. al., 2012). Beberapa manfaat bawang putih (Allium Sativum) yang sudah pernah diteliti adalah sebagai antijamur, antioksidan, antibakteri, antiprotozoa dan juga diyakini memiliki efek protektif terhadap sistem kardiovaskuler serta memiliki potensi sebagai antitumor (Majewski, 2014).

Bawang putih (Allium Sativum) memiliki aktivitas antibakteri terhadap berbagai bakteri patogen dalam tubuh manusia dan berspektrum luas serta efektif terhadap bakteri gram positif dan gram negatif (Onyeagba, et.al., 2006). Komponen utama yang berperan dalam antibakteri dan terapeutik adalah kandungan dari sulfur dalam bawang putih (Allium Sativum), diantaranya ialah Diallyl thiosulfinat (allicin) dan juga Diallyl disulfide (ajoene) (Dusica, et.al., 2011).

Beberapa hasil penelitian yang pernah menguji efektivitas ekstrak bawang putih dalam menghambat pertumbuhan bakteri seperti, penelitian yang dilakukan El-Mahmood (2009) dengan menggunakan ekstrak air bawang putih dapat menghambat pertumbuhan bakteri uji meliputi bakteri Staphylococcus Aureus, Escherichia Coli, Streptococcus Pneumoniae, dan 
Pseudomonas aeruginosa pada konsentrasi 40\%-70\%. Penelitian yang dilakukan Onyeagba et al. (2006) dengan menggunakan ekstrak etanol bawang putih (Allium Sativum) di kombinasi dengan lime (Citrus Aurantifolia Linn) mampu mengambat bakteri Bacillus spp., Staphylococcus aureus, Escherichia Coli, dengan masing-masing zona hambatnya $13 \mathrm{~mm}, 19 \mathrm{~mm}$, dan $11 \mathrm{~mm}$.

Penelitian ini bertujuan untuk mengetahui daya hambat ekstrak bawang putih (Allium Sativum) terhadap pertumbuhan bakteri Staphylococcus Aureus

\section{METODE PENELITIAN}

Penelitian ini menggunakan jenis penelitian uji eksperimental secara in vitro dengan desain Post test Only Control Group Design. Rancangan penelitian ini adalah Rancangan Acak Lengkap (RAL) dengan 6 kelompok perlakuan yang terdiri atas ekstrak bawang putih (Allium sativum) dengan konsentrasi $250 \mu \mathrm{g} / \mathrm{mL}, 500 \mu \mathrm{g} / \mathrm{mL}, 750$ $\mu \mathrm{g} / \mathrm{mL}, 1000 \mu \mathrm{g} / \mathrm{mL}$ dan 2 kelompok kontrol terdiri dari kontrol positif menggunakan ciprofloxacin dan kontrol negatif menggunakan aquades steril. Jumlah pengulangan tiap kelompok sebanyak 4 kali yang ditentukan berdasarkan rumus Federer.

Bawang putih yang digunakan diperoleh dari desa Sembalun, Kecamatan
Sembalun Kabupaten Lombok Timur. Bawang putih yang didapat dibersihkan menggunakan air, kemudian diiris tipistipis dan dikering anginkan tanpa terkena sinar matahari. Bawang putih yang sudah kering kemudian diblender sampai halus, di timbang seberat $250 \mathrm{~g}$ kemudian di ekstraksi dengan metode maserasi menggunakan pelarut etanol 96\% sebanyak $500 \mathrm{~mL}$ selama 24 jam dengan 2 kali pengulangan. Selanjutnya hasil maserasi disaring untuk memisahkan ekstrak etanol dan ampas bawang putih. Ekstrak etanol yang diperoleh diuapkan sehingga di dapatkan ekstrak kental bawang putih. Ekstrak bawang putih yang diperoleh diuji aktivitas antibakterinya terhadap bakteri Staphylococcus Aureus. Konsentrasi ekstrak bawang putih yang digunakan untuk uji antibakteri yaitu konsentrasi $250 \mu \mathrm{g} / \mathrm{mL}, 500 \mu \mathrm{g} / \mathrm{mL}, 750$ $\mu \mathrm{g} / \mathrm{mL}$, dan $1000 \mu \mathrm{g} / \mathrm{mL}$.

Masing - masing konsentrasi dimasukkan pada sumuran yang telah dibuat dengan diameter $6 \mathrm{~mm}$ pada media agar dengan jarak $\pm 15 \mathrm{~mm}$ masing masing sebanyak $100 \mu \mathrm{l}$ (Ainurrochmah et al., 2013). Hal yang sama juga dilakukan pada kontrol positif Ciprofloxacin dan kontrol negatif aquades steril. Selanjutnya media agar diinkubasi pada suhu $37^{\circ} \mathrm{C}$ selama 24 jam. Zona hambat yang terbentuk disekitar sumuran diukur dengan menggunakan penggaris. 
HASIL PENELITIAN

Penelitian tentang uji daya hambat ekstrak bawang putih (Allium Sativum) terhadap pertumbuhan bakteri Staphylococcus Aureus yang telah dilakukan di laboratorium Terpadu Fakultas Kedokteran Universitas Islam Al-Azhar. yaitu menggunakan ekstrak bawang putih (Allium Sativum) dengan konsentrasi $250 \mu \mathrm{g} / \mathrm{mL}, 500 \mu \mathrm{g} / \mathrm{mL}, 750$ $\mu \mathrm{g} / \mathrm{mL}, 1000 \mu \mathrm{g} / \mathrm{mL}$ yang dibandingkan dengan kontrol positif menggunakan antibiotik ciprofloxacin dan kontrol negatif menggunakan aquades steril. Masing-masing kelompok perlakuan diteteskan ke dalam media sumuran Blood Agar (BA) yang telah disuspensikan bakteri Staphylococcus Aureus dan dilakukan pengulangan sebanyak 4 kali. Hasil penelitian yang didapatkan di sajikan dalam Tabel 1.1 :

Tabel 1.1 Hasil Diameter Zona Hambat Ekstrak Bawang Putih (Allium Sativum) terhadap Pertumbuhan Bakteri Staphylococcus Aureus.

\begin{tabular}{|c|c|c|c|c|c|c|c|}
\hline \multirow{2}{*}{$\begin{array}{l}\text { Kelompok } \\
\text { perlakuan }\end{array}$} & \multicolumn{4}{|c|}{ Luas Zona Hambatan (mm) } & \multirow{2}{*}{$\begin{array}{c}\text { Jumlah } \\
\text { diameter }\end{array}$} & \multirow{2}{*}{ Rata-rata } & \multirow{2}{*}{ Makna } \\
\hline & 1 & 2 & 3 & 4 & & & \\
\hline $\begin{array}{l}\text { (k1) } 250 \\
\mu \mathrm{g} / \mathrm{mL}\end{array}$ & 14 & 0 & 12 & 0 & 26 & 6.5 & Resisten \\
\hline $\begin{array}{l}\text { (k2) } 500 \\
\mu \mathrm{g} / \mathrm{mL}\end{array}$ & 15 & 12 & 14 & 12 & 53 & 13.3 & Sensitif \\
\hline $\begin{array}{c}(\mathrm{k} 3) 750 \\
\mu \mathrm{g} / \mathrm{mL}\end{array}$ & 16 & 15 & 15 & 14 & 60 & 15 & Sensitif \\
\hline $\begin{array}{c}(\mathrm{k} 4) 1000 \\
\mu \mathrm{g} / \mathrm{mL}\end{array}$ & 18 & 18 & 19 & 16 & 71 & 17.8 & Sensitif \\
\hline Kontrol (+) & 14 & 13 & 15 & 14 & 56 & 14 & Sensitif \\
\hline Kontrol (-) & 0 & 0 & 0 & 0 & 0 & 0 & Resisten \\
\hline
\end{tabular}

Berdasarkan data pada Tabel 1.1 di atas didapatkan bahwa penambahan ekstrak bawang putih (Allium sativum) mampu menghambat pertumbuhan bakteri Staphylococcus aureus pada konsentrasi $250 \mu \mathrm{g} / \mathrm{mL}, 500 \mu \mathrm{g} / \mathrm{mL}, 750$ $\mu \mathrm{g} / \mathrm{mL}$, dan $1000 \mu \mathrm{g} / \mathrm{mL}$, dibuktikan dengan terbentuknya zona hambatan yang jernih di sekitar koloni bakteri Staphylococcus aureus. Konsentrasi ekstrak bawang putih (Allium sativum) $250 \mu \mathrm{g} / \mathrm{mL}, 500 \mu \mathrm{g} / \mathrm{mL}, 750 \mu \mathrm{g} / \mathrm{mL}$, dan
$1000 \mu \mathrm{g} / \mathrm{mL}$ menunjukan diameter zona hambatan rata-rata yaitu $6,5 \mathrm{~mm}, 13,3$ mm, $15 \mathrm{~mm}$ dan 17,8 mm. Pada kontrol negatif aquades steril tidak menghasilkan diameter zona hambatan $(0 \mathrm{~mm})$ dan kontrol positif ciprofloxacin menunjukan angka rata-rata $14 \mathrm{~mm}$.

Berdasarkan hasil uji bakteri dapat dilihat adanya daya hambat ekstrak bawang putih (Allium sativum) terhadap pertumbuhan bakteri Staphylococcus aureus pada berbagai konsentrasi 
terhadap zona hambatan seperti yang ditunjukan pada Gambar 1.1 di bawah ini

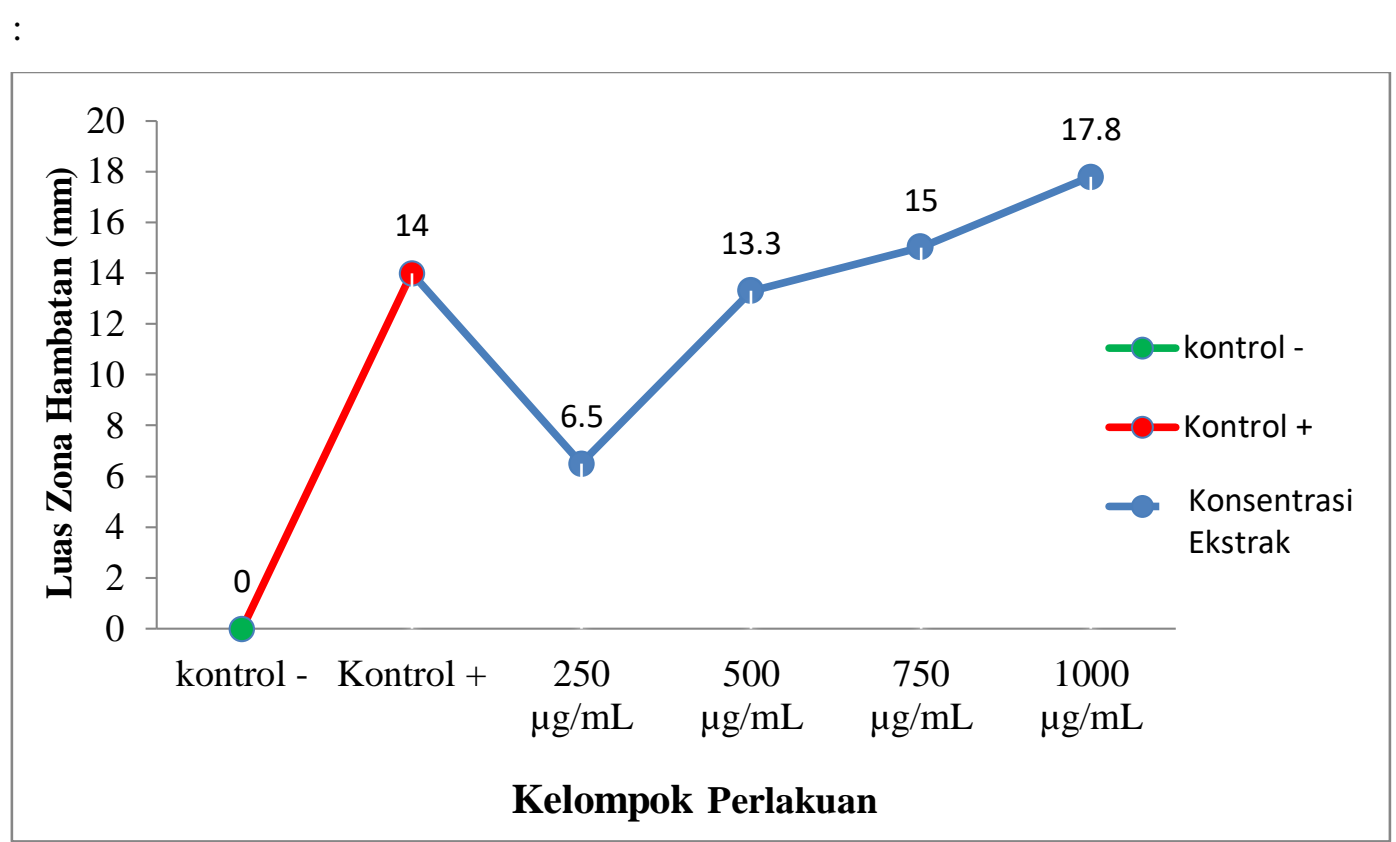

Gambar 1.1 Grafik daya hambatan ekstrak bawang putih (Allium Sativum), kontrol positif dan kontrol negatif terhadap pertumbuhan bakteri Staphylococcus Aureus.

Berdasarkan Gambar 1. Uji daya hambat ekstrak bawang putih (Allium Sativum) terhadap pertumbuhan bakteri Staphylococcus Aureus menunjukan bahwa zona hambat sudah terbentuk setelah masa inkubasi 24 jam pada suhu $37^{\circ} \mathrm{C}$ dimana pada konsentrasi $250 \mu \mathrm{g} / \mathrm{mL}$ terdapat zona hambatan $6,5 \mathrm{~mm}$, sedangkan pada konsentrasi $500 \mu \mathrm{g} / \mathrm{mL}$ diperoleh diameter zona hambat sebesar 13,3 mm, konsentrasi $750 \mu \mathrm{g} / \mathrm{mL}$ diameter zona hambatannya $15 \mathrm{~mm}$ dan konsentrasi $1000 \mu \mathrm{g} / \mathrm{mL}$ diameter zona hambatannya 17,8 $\mathrm{mm}$. Dapat dilihat bahwa semakin tinggi tingkat konsentrasi ekstrak bawang putih (Allium Sativum) maka diameter zona hambatan yang dihasilkan akan semakin besar akan tetapi persen peningkatan relatif kecil. Sedangkan diameter zona hambat untuk kelompok

kontrol positif yaitu $14 \mathrm{~mm}$, dan kontrol negatif tidak terdapat zona hambatan.

Analisis lebih lanjut mengenai uji daya hambat ekstrak bawang putih (Allium Sativum) terhadap pertumbuhan bakteri Staphylococcus Aureus dalam beberapa konsentrasi dilanjutkan dengan menggunakan uji statistik One Way Anova dan Tukey HSD. Hasil analisis statistik (One Way Anova) diperoleh $p$ value $0,008(\mathrm{p}<0,05)$ yang berarti ada perbedaan bermakna pada tiap kelompok konsentrasi ekstrak bawang putih (Allium Sativum), karena hasil yang didapatkan bermakna maka uji dilanjutkan dengan uji 
Post Hoc Test Tukey HSD untuk melihat besarnya perbedaan dari berbagai konsentrasi tersebut. Berdasarkan hasil uji Post Hoc Test Tukey HSD dapat dilihat bahwa perbandingan dua kelompok konsentrasi yang memiliki nilai $p$ value $<0,05$ menunjukan adanya perbedaan bermakna antara dua kelompok konsentrasi tersebut yaitu konsentrasi 250 $\mu \mathrm{g} / \mathrm{mL}$ dan konsentrasi $750 \mu \mathrm{g} / \mathrm{mL}$ adalah 0,042, serta konsentrasi $250 \mu \mathrm{g} / \mathrm{mL}$ dan konsentrasi $1000 \mu \mathrm{g} / \mathrm{mL}$ adalah 0,007. Sedangkan pada perbandingan konsentrasi $250 \mu \mathrm{g} / \mathrm{mL}$ dan konsentrasi $500 \mu \mathrm{g} / \mathrm{mL}(\mathrm{p}=0,123)$, konsentrasi 500 $\mu \mathrm{g} / \mathrm{mL}$ dan konsentrasi $750 \mu \mathrm{g} / \mathrm{mL}$ $(\mathrm{p}=0,920)$, konsentrasi $500 \mu \mathrm{g} / \mathrm{mL}$ dan $1000 \mu \mathrm{g} / \mathrm{mL}(\mathrm{p}=0,403)$, konsentrasi 750 $\mu \mathrm{g} / \mathrm{mL} \quad$ dan $1000 \quad \mu \mathrm{g} / \mathrm{mL} \quad(\mathrm{p}=0,757)$ dimana nilai $p$-value $>0,05$, sehingga tidak terdapat perbedaan yang bermakna antara dua kelompok konsentrasi tersebut artinya pada konsentrasi tersebut memiliki kecendrungan efek yang sama dalam menghambat pertumbuhan bakteri Staphylococcus Aureus.

\section{PEMBAHASAN}

Penelitian yang dilakukan adalah untuk mengetahui adanya daya hambat ekstrak bawang putih (Allium Sativum) terhadap pertumbuhan bakteri Staphylococcus Aureus dapat menggunakan uji kepekaan dengan metode sumur difusi. Apabila senyawa aktif yang terdapat pada ekstrak bawang putih (Allium Sativum) mampu menghambat pertumbuhan bakteri Staphylococcus Aureus maka akan terbentuk zona hambat di sekitar sumur difusi. Luas zona hambat tersebut selanjutnya diukur pada tiap-tiap konsentrasi.

Menurut Harmita dan Radji (2008), menjelaskan bahwa besar diameter zona hambatan yang dibentuk oleh obat-obatan tradisional dikatakan sensitive bila diameter zona hambatan > $18 \mathrm{~mm}$, intermediet bila diameter zona hambatan 13-17 mm dan resistent bila diameter zona hambatan $<12 \mathrm{~mm}$. Berdasarkan pernyataan tersebut dapat dikatakan bahwa ekstrak bawang putih (Allium Sativum) masuk dalam kategori Intermediet dan mampu menghambat pertumbuhan bakteri Staphylococcus Aureus dibuktikan dengan adanya zona hambatan yang terbentuk disekitar koloni bakteri Staphylococcus Aureus.

Berdasarkan penelitian yang telah dilakukan menunjukan bahwa ekstrak bawang putih (Allium Sativum) mampu menghambat pertumbuhan bakteri Stapyhlococus Aureus yaitu pada konsentrasi $500 \mu \mathrm{g} / \mathrm{mL}, 750 \mu \mathrm{g} / \mathrm{mL}$ dan $1000 \mu \mathrm{g} / \mathrm{mL}$ secara berturut-turut diameter zona hambatnya yaitu $13,3 \mathrm{~mm}$, $15,0 \mathrm{~mm}$ dan $17,8 \mathrm{~mm}$ sudah memperlihatkan adanya zona inhibisi. Sedangkan pada antibiotik ciprofloxacin 
diameter zona hambatnya yakni $14 \mathrm{~mm}$, relatif kecil karena dosis obat yang digunakan kecil disesuaikan dengan konsentrasi terkecil ekstrak bawang putih yaitu $250 \mu \mathrm{g} / \mathrm{mL}$, hal ini diketahui bahwa pada konsentrasi bawang putih (Allium Sativum) sudah memiliki daya hambat meskipun konsentrasi yang digunakan relatif kecil.

Besarnya zona hambat yang terbentuk terus meningkat seiring dengan bertambah besarnya konsentrasi bawang putih (Allium Sativum). Zona hambat terbesar adalah $17,8 \mathrm{~mm}$ pada konsentrasi $1000 \mu \mathrm{g} / \mathrm{mL}$ sedangkan zona hambat terendah adalah $6,5 \mathrm{~mm}$ pada konsentrasi $250 \mu \mathrm{g} / \mathrm{mL}$. Semakin tinggi konsentrasi ekstrak bawang putih (Allium Sativum) maka semakin banyak kandungan zat aktif di dalamnya sehingga aktivitas antibakterinya akan semakin besar dan juga sebaliknya semakin rendah konsentrasi ekstrak bawang putih (Allium Sativum) maka semakin sedikit zat aktif di dalamnya sehingga aktivitas antibakterinya akan semakin berkurang.

Berdasarkan hasil Post Hoc Test Tukey HSD dapat dilihat bahwa perbandingan dua kelompok konsentrasi yang memiliki nilai $p$ value $<0,05$ menunjukan adanya perbedaan bermakna antara dua kelompok konsentrasi tersebut yakni konsentrasi $250 \mu \mathrm{g} / \mathrm{mL}$ dan 1000 $\mu \mathrm{g} / \mathrm{mL}$ (0.007). Oleh karena itu, konsentrasi yang digunakan yang paling efektif adalah konsentrasi $1000 \mu \mathrm{g} / \mathrm{mL}$ dikarenakan luas zona hambatan yang dihasilkan paling luas dan berdasarkan hasil uji statistik nilainya signifikan.

Hasil tersebut tidak terlepas dari senyawa kimia yang terdapat pada ekstrak bawang putih (Allium Sativum) yang berfungsi sebagai antimikroba yaitu minyak atsiri, saponin, flavonoid, ajoene, alicin (Supardi, 2007). Menurut Djojoseputro tahun (2012), Minyak atsiri, tanin dan flavonoid berfungsi menghambat pertumbuhan bakteri dengan cara melibatkan perubahan dalam stabilitas molekul protein serta perubahan struktur protein, merusak membran sitoplasma sel dan menyebabkan kerusakan dinding sel. Protein yang mengalami proses denaturasi akan kehilangan struktur sekunder dan tersier, karena tekanan dari senyawa eksternal seperti alkohol atau klorofom ataupun panas yang akan menyebabkan ketidakstabilan pada dinding sel dan membran sitoplasma bakteri sehingga fungsi permeabilitas selektif, fungsi pengangkutan aktif, pengendalian susunan protein sel bakteri terganggu. Gangguan integritas sitoplasma berakibat pada lolosnya makromolekul, dan ion dari sel. Sel bakteri kehilangan bentuknya sehingga lisis.

Penelitian yang dilakukan ElMahmood (2009) menjelaskan bahwa bawang putih (Allium Sativum) mampu 
menghambat pertumbuhan mikroba Staphylococcus Aureus, Escherichia Coli,

S. Pneumoniae, dan Pseudomonas Aeruginosa ditandai dengan terbentuknya zona hambat hal ini dikarenakan ekstrak bawang putih (Allium Sativum) memiliki senyawa aktif yang bersifat sebagai aintimikroba seperti saponin, alkaloid, flavonoid, minyak atsiri, dan alicin.

Berdasarkan hasil penelitian dan hasil uji statistik, dapat disimpulkan bahwa ekstrak bawang putih (Allium Sativum) dapat menghambat pertumbuhan bakteri Staphylococcus Aureus.

\section{PENUTUP}

\section{Kesimpulan}

Berdasarkan hasil penelitian dan analisis data yang dilakukan dapat ditarik kesimpulan bahwa :

1. Diameter zona hambatan pada media sumuran mulai terbentuk pada perlakuan dengan konsentrasi terendah yaitu $250 \mu \mathrm{g} / \mathrm{mL}$ sebesar $6,5 \mathrm{~mm}$. konsentrasi $500 \mu \mathrm{g} / \mathrm{mL}$ sebesar 13,3 $\mathrm{mm}$, konsentrasi $750 \mu \mathrm{g} / \mathrm{mL}$ sebesar $15 \mathrm{~mm}$ dan diameter zona hambatan paling besar terlihat pada konsentrasi $1000 \mu \mathrm{g} / \mathrm{mL}$ sebesar 17,8 mm, kontrol positif menghasilkan zona hambatan $14.5 \mathrm{~mm}$ sedangkan kontrol negatif (aquades) tidak menghasilkan zona hambatan.

2. Uji statistik One Way Anova yakni $p$ value 0,008 yang berarti terdapat pengaruh yang signifikan pada ekstrak bawang putih (Allium Sativum) terhadap pertumbuhan bakteri Staphylococcus Aureus.

\section{Saran}

1. Bagi peneliti selanjutnya dapat digunakan sebagai rujukan untuk penelitian lebih lanjut ekstrak bawang putih (Allium Sativum) dengan menggunakan pelarut yang berbeda, variasi konsentrasi yang berbeda, menggunakan bagian lain dari tanaman bawang putih (Allium Sativum), maupun menggunakan bakteri dengan genus atau spesies yang berbeda.

2. Perlu dilakukan penelitian lebih lanjut dengan menggunakan kromatografi untuk mengisolasi zat antibakteri bawang putih (Allium Sativum) yang paling efektif dalam menghambat pertumbuhan bakteri Staphylococcus Aureus.

\section{DAFTAR PUSTAKA}

Ainurrochmah, A., Ratnasari, E., Lisdiana, L., 2013, Efektivitas ekstrak daun binahong (Anredera cordifolia) terhadap penghambatan pertumbuhan bakteri Shigella flexneri dengan metode sumuran. Jurnal Lentera Bio. 2 (3) : 233-7.

Ansari, et. al. (2016). Risk factors assessment for nasal colonization of Staphylococcus aureus and its methicillin resistant strains among pre-clinical medical students of Nepal. BioMed Central Research Notes, 9 : 214-221. 
Duman, A., 2008, Investigation of antibacterial effects of some medicinal plants and spices on food pathogens. Kalkas Univ Vet Fak Derg.

Dusica, P., Vesna, D., Ljubisa B, Mihajlo Z., 2011, Allicin and related compounds: biosynthesis and pharmacological activity. Phys Chem Tech.

Djojoseputro, S., 2012, Hantam Stroke dan Kanker Dengan Kunyit Putih. Stomata: Surabaya.

El-Mahmood, M., 2009, Efficacy of crude extract of garlic (Allium sativum Linn.), against nosocomial Eschericia coli, Staphylococcus aureus, Streptococcus pneumoniea, Pseudomonas aeruginosa, J Med Plants Res.

Fulder, S., Blackwood, J., dan Soetrisno, E., 2002, Buku Pintar Terapi Bawang.

Harmita dan Radji, M., 2008, Buku Ajar Analisis Hayati, Edisi 3, Jakarta : EGC.

Kemenkes RI, Profil Kesehatan Indonesia tahun 2012, Jakarta : Kemenkes RI; 2013.

Kowalski, J., W., 2007, Air-Treatment System for Controlling HospitalAcquired Infection. New York : Immune Building System Inc.

Majewski, M., 2014, Allium sativum: Facts and Myths Regarding Human Health, J Natl Ins Public Health.

Onyeagba, R., Uogbogu, O., Okeke, C., 2006, Studies on the antimicrobial effects of garlic (Allium sativum Linn), ginger (Zingiber officinale Roscoe) and lime (Citrus aurantifolia Linn). Afr. J. Biotechnol. 552-554 p.

Price Sylvia, A., dan Willson Lorraine, M., 2012, Patofisiologi : Konsep Klinis Proses-Proses Penyakit, Jakarta : EGC.
Supardi, A., 2007, Uji Aktivitas Antibakteri Ekstrak ik Umbi Bawang Putih (Allium sativum Linn.) Lanang terhadap Streptococcus pneumonia dan Klebsiella pneumonia secara dilusi. Skripsi, Fakultas Farmasi Universitas Setya Budi.

Tokajian, S., 2014, New epidemiology of Staphylococcus aureus infections in the middle east. Clinical Microbiology And Infection (CMI). 20(7): 624-628.

Wahyudi dan Sukarjati, 2013, Pengaruh Ekstrak Etil Asetat Getah Kamboja ( Plumeria acumenate. W.T. Ait) Terhadap pertumbuhan dan daya hambat Staphylococcus aureus Stigma. Vol. 06, No 02:27-30

WHO, 2013, Prevention Of HospitalAcquired Infection. A parctical guide $2^{\text {nd }}$ Ed., Departement of Communicable Disease, Surveillance and Response. USA. 